\title{
SHG-Bank Linkage in Andhra Pradesh: A Success Story
}

\author{
B. Seetharamaiah* \\ Ph.D..Research Scholar, Department of Economics, Sri Venkateswara University
}

*Corresponding Author: B. Seetharamaiah, Ph.D..Research Scholar, Department of Economics, Sri Venkateswara University

\begin{abstract}
Andhra Pradesh accounts for the largest number of SHGs credit linked, both in terms of number and the amount of credit. The credit resources accessed by the SHGs have been used for promoting the livelihoods of the member households. During 2016-17 alone, 385456 SHGs mobilized a total bank credit of Rs12246.11Crores, taking the outstanding loans to Rs. 13720.91 Crores by March 2017. Thus, in terms of growth of SHG savings and loan accounts as well as in terms of the amount of credit disbursed, the bank linkage programme has contributed significantly to financial inclusion and rural credit penetration in the state of Andhra Pradesh. The programme has contributed to the quality and sustainability of the community based organizations as well as to the diversification of the livelihoods of the poor. The SHG-bank linkage story of Andhra Pradesh has become a model for the rest of the country to adopt. The National Rural Livelihoods Mission (NRLM) of the Government of India has been designed on the success of the SHG bank linkage programme in Andhra Pradesh. Several factors have contributed to the success of the SHG-bank linkage programme in the state. An attempt is made in this paper to examine the growth in the SHG-bank linkage programme in Andhra Pradesh and the factors that have contributed to its success. An effort is also made to outline the pro-active role played by the GoAP in fostering SHG-bank linkage. The lessons learnt in Andhra Pradesh would be immensely useful to other states that seek to promote SHG-credit linkage.
\end{abstract}

\section{SHG BANK LINKAGE IN INDIA}

Launched in 1992, the SHG-bank linkage programme has emerged as a principal instrument of financial inclusion. The number of savings-linked SHGs in the country rose rapidly to reach about 79 lakhs and accounting for a total saving of Rs.13,691 Cr at the end of March 2016. The number of SHG loan accounts also increased rapidly to reach about 47 lakh (SHGs credit linked) by March 2016. The amount of bank credit disbursed to SHGs during 2015-16 alone amounted to Rs.37,287 Cr, while the outstanding loans stood at Rs.57,119 $\mathrm{Cr}$ as on $31^{\text {st }}$ March, 2016. Thus, in terms of growth of SHG savings and loan accounts as well as in terms of the amount of credit disbursed, the bank linkage programme has contributed significantly to financial inclusion and rural credit penetration in the country. Despite, relative stagnation in rural bank branch penetration, SHG-bank linkage programme has contributed to expansion in financial services to the rural population.

\subsection{SHG-BLP in Andhra Pradesh Vis-à-vis Other Southern States}

The SHG-bank linkage programme has not had a uniform impact across all regions of the country. The Southern States of Andhra Pradesh, Telangana, Karnataka and Tamil Nadu accounted for 45\% of the total SHG saving bank accounts with a cumulative saving of Rs.13,691 $\mathrm{Cr}$ (81\% of total) at the end of March 2016. On an average, each SHG had a cumulative saving of Rs.24,450/- in Southern region (March 2016), while all India average stood at Rs.17,324/-. The growth of SHGs in terms of number of savings and bank accounts, amount of savings, amount of loans disbursed and loans outstanding also recorded a substantially higher rates in Southern States compared to all India.

The inter-regional inequity is even more pronounced in respect of bank credit which has a direct impact on the members. The four states account for $72 \%$ of the total SHGs credit-linked, $80 \%$ of the credit disbursed during 2015-16 and 76\% of the outstanding bank loans. During 2015-16 alone, 11.59 lakh SHGs from these states were provided a total bank credit of Rs.30,012 Cr, while all other states accounted for a credit of Rs.7,275 Cr. The average outstanding loan per SHG in these states amounted to Rs.1,69,500/- (March 2016), while the all India average stood at Rs.1,22,242/-. Even in terms of quality of loans, the Southern region performed better with a low NPA of 4.1\% (March 2016), while the NPA for the country as a whole was $6.45 \%(\mathrm{Rs} .3,686 \mathrm{Cr})$. 
Table1. Growth of SHG-BLP in A.P. and Other Southern States: 2007-08 - 2015-16

\begin{tabular}{|l|l|l|l|l|}
\hline S. No. & Item & $\mathbf{2 0 0 7 - 0 8}$ & $\mathbf{2 0 0 1 5 - 1 6}$ & Growth (Percent) \\
\hline 1. & No. of SHGs with SB A/Cs (Lakh) & & & \\
\hline & Andhra Pradesh \& Telangana & 10.07 & 14.44 & 43 \\
\hline & Karnataka & 4.84 & 9.62 & 99 \\
\hline & Tamil Nadu & 6.18 & 8.52 & 38 \\
\hline & Total & $\mathbf{2 1 . 0 9}$ & $\mathbf{3 2 . 5 8}$ & $\mathbf{5 4}$ \\
\hline 2. & No. of SHGs credit linked (Lakh) & & \\
\hline & Andhra Pradesh \& Telangana & 8.08 & 12.95 & 60 \\
\hline & Karnataka & 2.32 & 6.32 & 172 \\
\hline & Tamil Nadu & 4.80 & 4.33 & $(-) 10$ \\
\hline & Total & $\mathbf{1 5 . 2}$ & $\mathbf{2 3 . 6}$ & $\mathbf{5 5}$ \\
\hline 3. & Outstanding loan amount (in Rs. Crore) & & & \\
\hline & Andhra Pradesh \& Telangana & 5386 & 27084 & 403 \\
\hline & Karnataka & 1390 & 7475 & 438 \\
\hline & Tamil Nadu & 2716 & 6359 & 134 \\
\hline & Total & $\mathbf{9 4 9 2}$ & $\mathbf{4 0 9 1 8}$ & $\mathbf{3 3 1}$ \\
\hline
\end{tabular}

Source: NABARD, Status of Micro-Finance in India, 2015-16

\section{SHG BANK LINKAGE IN AP}

The SHG-Bank linkage programme has made great strides in the state of Andhra Pradesh, as can be observed from the following Table-2. In 1999-2000, only 27,524 SHGs were credit linked in A.P. for an amount of Rs.56.60 Crores. Within a span of 10 years, the number of SHGs credit linked rose to 3,00,789 for a total amount of Rs.4,466 Crores. By 2016-17, the amount of credit rose to Rs.11,902 crore, registering an absolute growth of $20928 \%$ over 17 years.

Table2. SHG Bank Linkage Progress During 1999-2000 to 2016-17: Andhra Pradesh

\begin{tabular}{|c|c|c|c|}
\hline S. No. & Year & SHGs Covered & Credit Accessed by SHGs (Rs. In Lakhs) \\
\hline 1. & $1999-2000$ & 27524 & 5660 \\
\hline 2. & $2000-01$ & 61044 & 10541 \\
\hline 3. & $2001-02$ & 70106 & 15649 \\
\hline 4. & $2002-03$ & 104929 & 30881 \\
\hline 5. & $2003-04$ & 160053 & 59202 \\
\hline 6. & $2004-05$ & 180883 & 82294 \\
\hline 7. & $2005-06$ & 180659 & 134821 \\
\hline 8. & $2006-07$ & 234184 & 209602 \\
\hline 9. & $2007-08$ & 279019 & 401427 \\
\hline 10. & $2008-09$ & 300789 & 446576 \\
\hline 11. & $2009-10$ & 262701 & 442364 \\
\hline 12. & $2010-11$ & 244545 & 472870 \\
\hline 13. & $2011-12$ & 209688 & 512236 \\
\hline 14. & $2012-13$ & 249741 & 654812 \\
\hline 15. & $2013-14$ & 265118 & 824588 \\
\hline 16. & $2014-15$ & 188074 & 606505 \\
\hline 17. & $2015-16$ & 304202 & 1030839 \\
\hline 18. & $2016-17$ & 306224 & 1190170 \\
\hline
\end{tabular}

Source: MIS, APSERP

\subsection{District-wise SHG Bank Linkage in AP}

The progress of SHG bank linkage was uniform across all districts of the state. The number of SHGs bank linked rose significantly in respect of all districts of the state as can be observed from the following Table-3. In Chittoor district, the progress was even more significant. From 2,378 SHGs in 1999-2000, the number of SHGs credit linked rose to 25,638 by $2008-09$ and 39,107 by 2014-15. Along with the increasing number of SHGs, the amount of credit also recorded a significant increase from Rs.606 lakh SHGs in 1999-2000 to Rs.461 crores in 2008-09 and to Rs.1505 crores by 2014-15. Similar trends could be discerned across different districts of the state. The inter-district variations reflect the variations in the number of SHGs and their borrowing size. The borrowing size in turn 
depends on the borrowing history of the SHGs in the districts and their promptness in repayment. The response of the banks also influences the credit outgo.

Table3. District-wise SHG Bank Linkage : Andhra Pradesh

\begin{tabular}{|c|c|c|c|c|c|c|c|c|c|}
\hline \multirow[b]{2}{*}{$\begin{array}{c}\text { S. } \\
\text { No. }\end{array}$} & \multirow[b]{2}{*}{ District } & \multicolumn{2}{|c|}{1999 - 2000} & \multicolumn{2}{|c|}{ 2008-09 } & \multicolumn{2}{|c|}{ 2014-15 } & \multicolumn{2}{|c|}{ 2016-17 } \\
\hline & & $\begin{array}{c}\text { No. of } \\
\text { SHGs } \\
\text { Covered }\end{array}$ & \begin{tabular}{|c|} 
Credit \\
Accessed \\
by SHGs
\end{tabular} & $\begin{array}{c}\text { No. of } \\
\text { SHGs } \\
\text { Covered }\end{array}$ & \begin{tabular}{|c|} 
Credit \\
Accessed \\
by SHGs
\end{tabular} & $\begin{array}{c}\text { No. of } \\
\text { SHGs } \\
\text { Covered }\end{array}$ & $\begin{array}{c}\text { Credit } \\
\text { Accessed } \\
\text { by } \mathbf{S H G s}\end{array}$ & $\begin{array}{c}\text { No. of } \\
\text { SHGs } \\
\text { Covered }\end{array}$ & \begin{tabular}{|c|} 
Credit \\
Accessed \\
by $\mathbf{S H G S}$
\end{tabular} \\
\hline 1. & Anantapur & 1950 & 402 & 27173 & 34105 & 15917 & 51212 & 28527 & 972.26 \\
\hline 2. & Chittoor & 2378 & 606 & 25638 & 46139 & 39107 & 150473 & 47425 & 1429.28 \\
\hline 3. & East Godavari & 10700 & 1800 & 36537 & 55456 & 11658 & 37334 & 41048 & 1315.83 \\
\hline 4. & Guntur & 906 & 192 & 30284 & 41428 & 10143 & 31695 & 29111 & 899.69 \\
\hline 5. & Kadapa & 328 & 428 & 16718 & 22665 & 8327 & 26488 & 19174 & 661.13 \\
\hline 6. & Krishna & 2800 & 355 & 28524 & 46993 & 15531 & 53821 & 39791 & 1321.60 \\
\hline 7. & Kurnool & 826 & 330 & 18513 & 24780 & 13906 & 37588. & 22427 & 650.34 \\
\hline 8. & Nellore & 2012 & 433 & 14919 & 19585 & 7633 & 23021 & 22509 & 732.63 \\
\hline 9. & Prakasam & 723 & 289 & 20241 & 27592 & 16768 & 53366 & 31405 & 932.79 \\
\hline 10. & Srikakulam & 1210 & 200 & 17469 & 24952 & 18815 & 51334 & 27419 & 819.97 \\
\hline 11. & Visakhapatnam & 820 & 250 & 17385 & 29169 & 10422 & 32546 & 22492 & 755.93 \\
\hline 12. & Vizianagaram & 416 & 112 & 15484 & 25836 & 9581 & 24324 & 17414 & 586.89 \\
\hline 13. & West Godavari & 2455 & 262 & 31904 & 47876 & 10266 & 33303 & 36714 & 1167.78 \\
\hline 14. & AP Total & 27524 & 5660 & 300789 & 446576 & 188074 & 606505 & 385456 & 12246.12 \\
\hline
\end{tabular}

Source: MIS, APSERP

\subsection{Trends in SHG Bank Loans Outstanding}

While the total states had an outstanding number of loan accounts of 4,27,296 in March, 2017 for an outstanding amount of Rs.6,497 Crores, the average outstanding loan for the state was Rs.1,69,069/per SHG. This is a clear indication of the growing importance of bank loan portfolio in the SHGs. It is no exaggeration to say that SHG bank linkage has emerged as the principal stay of SHG finances today. This is more so after the introduction of cash-credit loans which allows the SHGs the flexibility required to borrow and repay increasing amounts at frequent intervals.

However, considering the expanding needs of SHG members, there is a need to augment credit flow to the SHG members as demand for credit is high more so for livelihood activities. There is a need to ensure higher credit flow as the credit flow from banking sector is not adequate for various reasons as the average credit flow per SHGs is at Rs.2.60 lakh translating into Rs.25,000/- per borrower.

\subsection{Term Loans and Cash-Credit Loans}

Term loans do not give the flexibility necessary for the SHGs to repay at quick intervals and borrow on a continuous basis. SHGs were required to wait till the entire term loan is repaid before borrowing another loan. To overcome this constraint and based on the recommendations of NABARD, the commercial banks have introduced cash-credit loans. Each SHG sanctioned CCL is indicated a limit within which it can borrow and repay any number of times depending on the need and repaying capacities. The limits get enhanced, based on the repayment history of the SHGs. Rate of interest is paid only on the amount outstanding in a given period. APSERP has guided all SHGs under its fold to adopt the CCL route, which has proved to be very effective in terms of the number of SHGs credit linked, limit sanctioned and amounts disbursed. The cash-credit loans of SHGs in the state as outstanding in March 2017 are furnished in Table. The SHGs credit linked during 2016-17 are detailed in Table. The data furnished in the Table indicates the fact that bank credit to SHGs has virtually become the life-blood of the SHGs.

Table. No. of SHGs with Cash-Credit Loans Outstanding

Mar. '17

\begin{tabular}{|l|l|l|l|l|l|}
\hline $\begin{array}{l}\text { S. } \\
\text { No. }\end{array}$ & Geography & $\begin{array}{l}\text { No of SHGs with } \\
\text { Borrowings } \\
\text { Outstanding }\end{array}$ & $\begin{array}{l}\text { No of Borrowing } \\
\text { A/cs Outstanding } \\
\text { with SHGs }\end{array}$ & $\begin{array}{l}\text { Total Borrowing } \\
\text { Amount Outstanding } \\
\text { (Rs, Lakhs) }\end{array}$ & $\begin{array}{l}\text { Average Borrowing } \\
\text { Amount Outstanding per } \\
\text { SHG (in Rupees) }\end{array}$ \\
\hline 1. & State & 4999 & 5139 & 125.25 & 250554 \\
\hline
\end{tabular}

Source: MIS, APSERP 
Table. SHGs Credit Linked During 2016-17

\begin{tabular}{|c|c|c|c|c|c|}
\hline $\begin{array}{c}\text { S. } \\
\text { No. }\end{array}$ & $\begin{array}{c}\text { No. of SHGs } \\
\text { Provided Bank } \\
\text { Loans (CCL) }\end{array}$ & $\begin{array}{c}\text { No. of } \\
\text { SHGs } \\
\text { Disbursed }\end{array}$ & $\begin{array}{c}\text { Amount } \\
\text { Disbursed } \\
\text { (Rs, Lakhs) }\end{array}$ & $\begin{array}{c}\text { Percent of Targeted } \\
\text { SHGs Provided Bank } \\
\text { Loans }\end{array}$ & $\begin{array}{c}\text { Percent of Targeted } \\
\text { Loan Amount } \\
\text { Disbursed }\end{array}$ \\
\hline 1. & State & 385456 & 12,246 & 73.3 & 107.71 \\
\hline 2. & Average Per SHG & -- & 317702 & & \\
\hline
\end{tabular}

Source: MIS, APSERP

\subsection{Factors Contributing to Bank Linkage in AP}

Several factors have contributed to the growth of SHG bank linkage in all districts of the state, with SERP playing a key role as briefly described below. Implementation of UNDP funded South Asia Poverty Alleviation Programme (SAPAP) in three districts during 1996-2001. Built on a three-tier community institutional architecture viz., SHGs, Village Organizations (VOs) and Mandal Samakyas (MSs), the SAPAP provided immense learning for the SHG-centered programmes implemented by GoAP subsequently and for their bank linkage eventually.

Based on the learning from SAPAP, the GoAP established a dedicated organization for rural poverty alleviation in 2000 known as the Society for Elimination of Rural Poverty (SERP). The autonomous society under the Ministry of Rural Development of GOAP is chaired by the Chief Minister and includes Minister of Rural Development, Principal Secretary, Rural Development, Commissioner, Rural Development, Commissioner, Tribal Welfare, among others as members to provide overall direction and guidance for implementation of poverty alleviation programmes. The mandate of SERP includes:

- promotion of social mobilization and community institution building (SHGs and their federations) for poverty alleviation and livelihoods promotion;

- training and capacity building of community institutions, community resource persons and professional staff of SERP, line departments, bankers and other stakeholders;

- promotion of financial inclusion through CBO-based micro-finance activities and SHG-bank credit linkage as well as promotion of innovations in SHG-bank linkage;

- sensitization and support to banks and other financial institutions for credit delivery and recovery;

- promotion of livelihoods of the poor through technical and financial support as well as skill development;

- sensitization of all line departments to be inclusive of the needs of the poor; and

- promotion of convergence between the rural poor, their institutions and the line departments.

\section{SERP AS THE IMPLEMENTING Agency FOR SHG-CEnTRIC POVERTy Alleviation PROGRAMMES}

SERP was made the principal agency for implementing all SHG-centric poverty alleviation programmes in the state. In order to facilitate implementation, dedicated architecture has been created at the state, district and mandal levels with multi-functional specialists. The State Project Management Unit (SPMU) headed by a Chief Executive Officer (All India Service Officer) comprises 15 high quality specialists in SM, IB \& CB, FI, Livelihoods, Partnerships, Jobs, Marketing, Agriculture, Health \& Nutrition, Social Security, Gender, Disability, ICT etc., who provide direction, guidance and support to the implementation of projects. Each district has a DPMU housed in DRDA also includes experts (10 to 15) in the core component areas of the project who actually spearhead project implementation with the support of Area Coordinators (10 to 12 per district). Each Area Coordinator in turn facilitates implementation of the SHG-centered projects in 5 to 6 mandals with the support of Community Coordinators (3 to 6) and Assistant Project Managers (1 per mandal) following the standard operating guidelines of the projects.

\subsection{Implementation of Externally-Aided Projects}

Based on the learning from SAPAP, the SERP had implemented major SHG-centered rural poverty alleviation projects known as APDPIP (2000-2004) and APRPRP (2004-2010). Both the projects had 
four core components woven around SHGs and their federations viz., social mobilization and institution building, community investment support, financial inclusion, livelihoods promotion and convergence. Implementation of these projects for about a decade covering all rural areas provided the necessary fillip to the SHG-BLP. Both the projects had extensively promoted SHG-credit linkage as a principal tool for financial inclusion of the poor. Along with the World Bank funding, the GOAP has provided substantial financial resources, technical and policy support to the SHG-based livelihood programmes in the state. The SERP is currently implementing Andhra Pradesh Rural Inclusive Growth Project (APRIGP), a third-phase project funded by the World Bank but anchored on SHGs and their federations.

\subsection{Four-Tier Community Institutional Architecture}

As part of its poverty alleviation programme (Velugu), SERP has promoted a four-tier inter-linked community institutional architecture viz., SHGs, VOs, MSs and ZSs. While the SHG is the foundation, the other institutions are its federations and all of these are registered under APMACS Act. The SHGs and federation are inter-linked through systematic governance and financial relations. The VOs provide not only CIF loans to the SHGs but also facilitate their access to bank credit through capacity building, preparation of micro-plans and loan applications, monitoring and recovery of bank loans through sub-committee system known as Community Based Recovery Mechanism (CBRM) at all bank branches.

\subsection{Systematic Capacity Building}

SERP has been a pioneer in promoting systematic capacity building of community institutions and training of professional staff using standard modules. The SHGs have been systematically trained by the programme staff, training institutions and community trainers or resource persons in Panch Sutras which in turn facilitate SHG-credit linkage. The focus on regular savings, inter-lending, repayment and bookkeeping as part of capacity building have contributed a great deal to the financial awareness and discipline of the members. The VOs/staff also undertake rating of SHGs (using NABARD tool) as part of facilitating sanction/renewal of bank loans. The MSs also provide capacity building support to the VOs and SHGs in promoting SHG credit linkage through liaison with the banks/ bankers committees.

\subsection{Use of Community Investment Fund}

CIF has been provided to all MSs and VOs under the World Bank funded projects. This fund has been extensively used to provide loans to most SHGs to enable them to meet consumption and livelihood requirements of members. The extensive use of this catalytic capital has not only promoted financial discipline among the SHGs but also enabled them to access bank loans and service them.

\subsection{Bookkeeping Support}

SERP is the first organization in the country to have introduced the cadre of Master Bookkeepers (MBKs) who train community bookkeepers and provide accounting and audit advice and support to the SHGs and VOs. The role of MBKs is critical in promoting e-bookkeeping of SHGs introduced in Andhra Pradesh.

\subsection{Bank Mitras}

To facilitate SHG-bank linkage and to minimize the cost of transactions to the bankers, SERP has introduced Bank Mitras, a cadre of community professionals trained in the preparation of loan applications and other documents. Bank Mitras have emerged as an important cadre facilitating not only sanction of bank loans but more importantly their timely disbursal and repayment. The honorarium of Bank Mitras is met out of the contributions of the SHGs.

\subsection{Streenidhi Operations}

The setting-up of state level women cooperative bank under the umbrella of SERP (discussed later in this chapter) has further strengthened the financial discipline among the SHGs. The procedures instituted for sanction of loans to SHG members under Streenidhi are designed to avoid excessive lending from multiple sources. Each MS maintains database of all SHGs and their member borrowings from banks, CIF, Streenidhi and from internal sources. MS plays a central role in sanction and disbursal of CIF and Streenidhi loans as well as monitoring the repayment of bank loans. 


\subsection{Sensitization of Bankers and Others}

Recognizing the pivotal role played by the bankers in the SHG-bank linkage, SERP has undertaken extensive sensitization of bankers to the SHG practices and oriented them to SHG-lending. Several exposure visits to best practicing SHGs were organized. Coupled with the NABARD training programme, the sensitization programme of SERP has contributed to the rapid growth of SHG-bank linkage in AP. Specially designed sensitization programmes were organized for people's representatives, officials of the line departments and other stakeholders which have also contributed to SHG-bank linkage.

\subsection{Policies of GOAP}

In order to strengthen SHG-BLP, GOAP has introduced several policies over a period of time which have contributed to SHG-bank linkage. Important among these policies relate to: $(i)$ introduction of interest subsidy/interest subvention/ zero interest loans to SHGs; (ii) exemption of stamp duty for bank loans to SHGs; (iii) allocation of CIF to all MSs and VOs; (iv) using services of SHGs for providing mid-day meals in government schools; (v) using SHGs and federations as agents for procuring paddy/ maize/other agricultural commodities; (vi) using services of SHGs for distributing different types of pensions, dispensing generic medicines, procurement of milk and running of bulk milk cooling centers; and (vii) micro-insurance agents (as well as beneficiaries).

\subsection{Extensive Use of ICT}

SERP has been a pioneer in the use of state of the art ICT services to monitor SHG-Bank Linkage. A dedicated web-portal (bank linkage portal) anchored on Core Banking Solutions (CBS) platform has been in operation for tracking sanctions, disbursal and repayment of term loans as well as cash credit loans to SHGs. All transfers to SHGs including transfer of interest subvention and other benefits are being made online. E-bookkeeping has been introduced covering all SHGs in the state through mobile telephony. All MSs and ZSs have been provided computer infrastructure, trained computer staff along with software technology applications. All SHG transactions are integrated into online MIS. A wide variety of reports are available to the programme staff and community institutions to facilitate supervision, monitoring and review.

\subsection{Extensive Banking Network}

One of the significant factors contributing to SHG-BLP in AP is the extensive network of commercial banks and RRBs as well as cooperative banks. The high density of banks, coupled with a favourable eco-system has contributed to the rapid strides in SHG-Bank Linkage.

\subsection{Proactive NABARD, SLBC and Banks}

The NABARD and banking system too played a significant role in the expansion of SHG-Bank Linkage in the states. Some of the important initiatives that were introduced in AP but have eventually transformed SHG-Bank Linkage in the rest of the country include: (i) simplification of standardization of loan documents; (ii) introduction of critical rating mechanism for SHGs; (iii) introduction of standardized books of accounts; (iv) setting-up of SLBC sub-committees for monitoring SHG-BLP; $(v)$ introduction of SHG-BLP performance as a review parameter; $(v i)$ introduction of performance awards for SHG-BLP for banks by NABARD; (vii) introduction of standard books of accounts for SHGs; (viii) standardization of modules for sensitization of banks and government staff; and (ix) setting-up of women development cells in RRBs and cooperative banks.

\subsection{Interest Subsidy (Vaddileni Runalu)}

With a view to encouraging better repayment and to reduce the interest burden on the rural poor for the loans taken by self-help groups from banks and to improve the profitability of the SHGs and their enterprises / livelihood activities, Government of AP has been implementing a full interest subvention on SHG bank loans since 01.01.2012. All SHGs in the rural areas which have an outstanding bank or Streenidhi loan as on 01.01.2012 or thereafter are eligible for interest subvention subject to the following:

- The loan should not exceed Rs.5.00 lakhs, if it is a term loan;

- In case of CCL loan, the SHG shall repay at least $3 \%$ of the outstanding principal amount each month; 
- Only the monthly repayments made within the first 7 days from the due date are eligible for interest subvention for that month;

- Eligibility is verified on a month-to-month basis;

- In case of overdue accounts, such SHGs have to clear the amount in excess of the scheduled outstanding as on 01.07.2012;

\subsection{NRLM Interest Subvention}

In addition, the NRLM provides an interest subvention equal to the difference between lending rate and $7 \%$ to SHGs. Further, an additional incentive of 3\% is provided as subsidy to the SHGs which make prompt repayment. However, even the SHGs provided subsidy under NRLM account are also eligible for 'zero percent' interest with they comply with the conditions laid down.

\subsection{Trends in Zero Interest Loans}

It can be observed that the number of SHGs eligible for interest subsidy as well as the number of loans eligible for subsidy have been on the increase right from 2010-11. The number of SHGs rose from 3.98 lakh in 2010-11 to 5.66 lakh by 2016-17. The number of loans processed rose from 6.93 lakh to 6.68 lakh during the same period. However, the number of loans eligible is smaller than number of loans processed in each year. The difference between the two the number of loans considered ineligible for different reasons including failure to comply with the repayment norms to be eligible for interest subsidy. The amount of subsidy, however, steadily rose from Rs.252 crores to Rs.705 crores for the entire state during 2010-11 to 2016-17. The interest subsidy scheme has therefore effectively facilitated provision of bank loans year after year without any interest cost in the state.

Table. Details of Year-wise Zero-Interest Loans: Andhra Pradesh

Rs. Lakhs

\begin{tabular}{|c|c|c|c|c|c|}
\hline S.No. & Year & No. of SHGs & $\begin{array}{c}\text { No. of Loans } \\
\text { Processed }\end{array}$ & $\begin{array}{c}\text { No. of Loans } \\
\text { Eligible for VLR }\end{array}$ & VLR Amount \\
\hline 1. & $2010-11$ & 397606 & 692803 & 485053 & 25,154 \\
\hline 2. & $2011-12$ & 553137 & 806693 & 621120 & 48,412 \\
\hline 3. & $2012-13$ & 583457 & 985787 & 785536 & 61,282 \\
\hline 4. & $2013-14$ & 579726 & 807576 & 682051 & 80,934 \\
\hline 5. & $2014-15$ & 565561 & 689338 & 534057 & 46,518 \\
\hline 6. & $2015-16$ & 583123 & 779223 & 616782 & 78,220 \\
\hline 7. & $2016-17$ & 566143 & 667726 & 565618 & 70,490 \\
\hline
\end{tabular}

Source: MIS, APSERP

\section{SUMMARY AND CONCLUSION}

Bank loans have emerged as the single largest and elastic source of borrowing for the SHGs. SHGs repaying loans regularly, the source has potential to provide unlimited financial resources to meet the livelihood finance requirements of the members. Andhra Pradesh has emerged as leader in SHG bank linkage, both in terms of number of SHGs bank linked as well as the amount of bank credit. During 2016-17 alone, the total credit to Rs.11,902 Cr to 3.06 lakh SHGs. Even among the southern states, Andhra Pradesh has been leading in SHG bank linkage. The picture is more or less uniform across different districts of the state. The four sample mandals also reflect similar trends in SHG borrowings from the banks. The total outstanding loan amount of all SHGs stood at Rs.6497.00 Cr in March 2017 (4.27 lakh borrowing accounts of 3.84 lakh SHGs). Similar trends could be observed in the sample district and across the sample mandals. The SHG borrowings have registered significant increase both in terms of number of borrowing accounts and the amount of borrowing after the introduction of cash credit system. Thus in March 2017, the amount of loan disbursed exceeded the target by 7\%, with each SHG borrowing an average amount of Rs.3.17 lakh.

Several factors have contributed to SHG bank linkage in A.P. The early social mobilization and SHG formation efforts undertaken under UNDP-SAPAP, establishment of APSERP, implementation of the World Bank funded APDPIP and APRPRP, introduction of interest subsidy/subvention schemes, enactment of Micro-Finance Regulation Act of 2011, use of ICT solutions for close monitoring of SHG bank linkage and repayment, setting-up of Streenidhi bank, use of bank mitras to facilitate SHG 
loan transactions, sensitization of bankers, institution of CBRM and the use of SHG as a medium for implementation of several programmes of GoAP, have accounted for the steep increase in SHG bank linkage in A.P.

\section{REFERENCES}

[1] APMAS, Microfinance Consensus Guidelines, APMAS: Hyderabad, 2003.

[2] CESS, Andhra Pradesh Rural Poverty Reduction Project (APRPRP), CESS, Hyderabad.

[3] CESS, Report of Baseline Survey of APDPIP, CESS, Hyderabad.

[4] CESS, Report of Baseline Survey of APRPRP, CESS, Hyderabad.

[5] CESS, Report of Mid-line Survey of ADPIP, CESS, Hyderabad.

[6] CESS, Reports of Impact Evaluation of APDPIP and APRPRP, CESS, Hyderabad.

[7] DHAN Foundation, A Study on Social Mobilization and Micro-Credit for Women's Empowerment, APMAS.

[8] Hemalatha Prasad C., Social Mobilization, Employment and Empowerment of Women through SHGs, NIRD, Hyderabad, 2006.

[9] Imran Sharif Chaudhry, Women Empowerment in Contemporary Development Policies, World Development, Vol.29, p.4, 2009.

[10] Joseph Sybi Mon, Sustainability of Micro Enterprises Runs by Self Help Groups in Kerala: Doctoral Dissertation to Gandhigram Rural University, Dindigul, 2007.

[11] Manimekalai, N., Impact of Various Forms of Micro-Finance on Women, Bharathidasan University, Tiruchirapalli, 2004.

[12] MORD, Report of the Committee on Credit Related Issues Under SGSY, Ministry of Rural Development, Government of India, 2009.

[13] NABARD, A Handbook on Forming Self Help Groups, NABARD, 1993.

[14] NABARD, Banking with the Poor, Financing Self Help Groups, NABARD, Hyderabad, 2000.

[15] Purushotham P., National Study on SGSY, A Process Study Centres for Self Employment and Rural Enterprise, NIRD, Hyderabad, pp.132, 2006.

[16] Ramakrishna R. et.al., Micro-Credit for Rural Youth through SHGs, Cooperative Perspectives, Vol.38 (3), pp.48-59.

[17] Rao V.D., Emancipation of Women through Self-Management - A Study in Andhra Pradesh, Man and Development, 26(1), pp.115-134.

[18] Robert Christen \& Goutham Ivatury, A Systematic View of SHG Bank Linkage - Four Sustainable Models, 2005.

[19] Robert Hunter, International Review of Applied Economics, Vol.26 (3): pp.223-239, 2012.

[20] Second Human Development Report, Andhra Pradesh, CESS, Hyderabad.

[21] SERP, Andhra Pradesh State Perspective and Implementation Plan (APSPIP), Vol. I submitted to NRLM, MORD, Government of India, 2013.

[22] SERP, VELUGU Progress Report, SERP: Hyderabad, India, May, 2008.

[23] Singh S., Dynamics of Self Help Group Formation, Ph.D. Thesis, Kerala Agriculture University, 2003.

[24] The MYRADA Experience: A Manual for Capacity Building of Self Help Groups, MYRADA: Bangalore, 2000.

[25] The World Bank, Project Appraisal Document (PAD) of National Rural Livelihoods Project (NRLP), Report No. 59393-IN, The World Bank, June 3, 2011.

[26] The World Bank, World Development Report 2000/2001: Attacking Poverty, Washington D.C : The World Bank, 2000.

[27] UNICEF, Report on Women's Economic Empowerment, UNICEF, 2007.

\section{Books}

[28] Jaya S., Anand, "Self Help Groups in Empowering Women, A Case Study of Selected SHGs and NHGs", Rainbow Publishers, Noida, UP, 2002.

[29] Kamla-Raj, "Women Empowerment in Decision Making Ability - Self Help Group Approach", Vikas Publishing House (P) Ltd., New Delhi, 2008.

[30] Krishnaraj, Maithreyi and Karuna Chanan (Edt), "Gender and the Household Domain Social and Cultural Dimensions", Sage Publications, New Delhi. 
[31] Lalitha N. and Nagarajan B.S., "Self Help Groups in Rural Development", Dominant Publishers and Distributors, pp.230, New Delhi, 2002.

[32] Murthy S., “Women and Empowerment”, RBSA Publishers, Jaipur, 2005.

[33] Narayan, Deepa Robert Chambers, Meera K. Shah and Patti Petesh, "Voices of the Poor : Crying out for Change", New York : Oxford University Press, 2000.

Citation: B. Seetharamaiah. "SHG-Bank Linkage in Andhra Pradesh: A Success Story" International Journal of Managerial Studies and Research (IJMSR), vol 6, no. 3, 2018, pp. 25-33. doi:http://dx.doi.org/10.20431/2349-0349.0603004.

Copyright: (C) 2018 Authors. This is an open-access article distributed under the terms of the Creative Commons Attribution License, which permits unrestricted use, distribution, and reproduction in any medium, provided the original author and source are credited. 